\author{
산림 바이오매스의 에너지 활용을 위한 타당성 분석 \\ 강현구 · 박기철 · 김래현 ${ }^{\dagger}$ \\ 서울과학기술대학교 에너지환경대학원 \\ (2013년 2월 27일 접수, 2013년 11월 20일 수정, 2013년 12월 10일 채택)
}

\title{
The feasibility analysis for energy utilization of forest biomass
}

\author{
Hyeun Koo Kang · Kee Chul Park · Lae Hyun Kim ${ }^{\dagger}$ \\ Graduate School of Industry, Seoul National University of science and Technology
}

(Received 27 February 2013, Revised 20 December 2013, Accepted 10 December 2013)

요 약

본 연구에서는 전국적으로 48만ha에 걸쳐 연료림으로 조성되어 있는 리기다소나무를 에너지연료로 활용하기 위해 최적의 생산시스템을 개발하고 이에 따른 공급가격과 전기·열 판매가격 및 이용률 등을 고려한 우드칩 연료한계가격을 산출하였으며 다양한 시나리오에 따른 경제성 민감도 분석을 수행하였 다. 열 및 발전 전용시설에서의 경제성을 결정짓는 가장 중요한 변수는 연료공급가격이다. 열 전용시 설에서는 본 연구에서 제안된 모든 생산시스템에서 생산되는 우드칩 연료의 활용이 가능하며 발전 전용시설에서는 생산비가 가장 높은 연료사용에는 일부 한계가 있으나 전기 판매가격이 현재의 $\mathrm{SMP}$ (pitch pine : 계통한계가격)보다 높아지거나 이용률이 $80 \%$ 이상으로 되는 경우 모두 활용 가능한 것으로 분석되었으며, 더욱이 RPS제도 시행에 따른 신재생에너지 인증서(REC:Renewable Energy Certificate)편익과 온실가스 절감효과로 $\mathrm{CDM}($ Clean Development Mechanism)편익 등을 고려할 경우 충분히 활용 가능한 것으로 분석되었다. 따라서, 국내 발전부문에서의 RPS 공급의무율 이행을 위해서 산림 바이오매스의 활용이 적극 권장된다.

주요어 : 우드칩, 연료한계가격, 리기다소나무

\begin{abstract}
The optimal woodchip production system was developed and the production cost of a forest woodchip fuel was calculated for utilizing the pitch pine, which covers around 480,000ha nationwide. the marginal price of the woodchip fuel considering the factor of supply price, electricity and heat selling price as well as capacity factor were suggested and the economic sensitivity analysis was conducted for various scenario. The most important variable which determine economic feasibility was a fuel cost for the power generation facility. If the electricity price is higher than the current SMP(System Marginal Price) or the capacity factor is higher than $80 \%$, there fully is a benefit to consume the woodchip fuels produced in the suggested production system in this study. In addition, the additional benefit becomes more obvious when considering REC(Renewable Energy Certificate) and CDM(Clean Development Mechanism). Therefore, it is strongly suggested for domestic power generation sector to utilize the forest biomass fuel to achieve the obligatory target of RPS.
\end{abstract}

Key words : forest woodchip fuel, System Marginal Price, pitch pine

\footnotetext{
${ }^{\dagger}$ To whom corresponding should be addressed.

Seoul National University of Technology, 172, Gongneung

2 Dong, Nowon-Gu, Seoul, Korea

Tel : 970-6620Ｅ-mail : lhkim@snut.ac.kr
} 


\section{1. 서 론}

기후 변화대응 및 화석연료 고갈에 대한 대응방안 으로 정부는 신재생에너지 보급을 적극적으로 추진하 고 있는 바 국내 부존자원으로서 활용 가능한 산림 바이오매스 에너지의 중요성이 또한 증대되고 있다. 이에 그동안 산림 바이오매스를 활용하기 위한 시범 사업과 연구가 많이 이루어져 왔으나 그 대부분이 목 재 생산을 위한 연구에 집중되어 있었으며 에너지 활 용을 위한 연구는 부족한 실정이다 $[1,3,13,15,22$, 24, 25,2 8].

2006년 국내 최초로 서대구에 목질계 바이오매스 열병합발전소가 준공되어 상업운전에 들어간 이후 몇 개의 열병합발전소가 추가로 건설되어 운영 중에 있 으며 현재는 RPS제도 시행에 대응하기 위해 한전의 발전자회사인 한국동서발전이 2013년 준공목표로 동 해에 $30 \mathrm{MW}$ 급 목질계 바이오매스 발전소를 건설 중 에 있으며 한국수력원자력과 한국서부발전도 30 50 $\mathrm{MW}$ 급의 목질계 바이오매스 발전소 건설을 계획하고 있으며, 한국지역난방공사와 민간부문에서도 목질계 바이오매스 열병합발전설비 건설을 계획하고 있다 $[1,8,9,14,17,26]$.

이처럼 한전 발전자회사를 포함한 13개 RPS 대 상 발전사업자들과 여러 민간열병합 발전사업자 및 산업용 열 생산 설비 보유업체들이 목질계 바이오매 스 에너지의 이용계획을 적극 검토하고 있으나 목질 계 바이오매스연료의 높은 공급가격과 공급의 안정성 을 우려하여 쉽게 시행을 못하고 있는 것이 현실이다 $[1,9,16,18,29,30]$.

목질계 바이오매스 에너지 활성화의 관건은 공급 가격의 경제성과 공급의 안정성이 확보되어야 하는바 이러한 문제점의 해결방안을 도출하기 위해 본 연구 에서는 목질계 바이오매스중의 하나인 산림 바이오매 스로 국내 부존자원이며 1960 1970년대에 걸쳐 전국 적으로 48 만ha에 연료림으로 조성하여 현재는 벌기 령이 지나 수종갱신 대상인 리기다소나무를 에너지연 료로 활용하기 위한 에너지연료 생산공정분석을 통한 생산비용을 산출하고 또한 현 단계에서 생산비용을 최소화 할 수 있는 최적의 생산시스템을 개발하여 현 재의 에너지 생산시스템에 적용 시 경제성 확보 여부 를 경제성분석을 통해 확인하고 이에 따른 경제적 편익분석과 환경적 편익분석을 종합하여 산림 바이오 매스 에너지의 활용가능 타당성을 평가하고 활성화를
위한 방안을 제시하고자 한다[2,8].

또한 에너지 연료 활용을 위한 산림 바이오매스 의 생산비용 및 공급가격을 에너지 생산시스템(열 전 용시설, 발전 전용시설)별로 적용 열·전기 판매가격 및 이용률 등을 고려한 우드칩연료 한계가격을 산출 하고 다양한 시나리오에 따른 민감도 분석을 수행하 여 산림 바이오매스의 에너지 활용을 위한 타당성을 분석하고자 한다. [2,11,16,21].

\section{2. 공정분석에 따른 리기다소나무 연료생산 표준단가 산출}

산림 바이오매스가 에너지로서의 활용 가능성이 있는지 여부를 검증하기 위해서는 산림 바이오매스의 단위 생산비용 및 공급가격의 산정이 선행되어야 한 다[30].

산림 바이오매스의 생산비용 및 공급가격은 숲 가 꾸기 사업 부산물 용재생산용 벌목사업 부산물 또는 에너지활용을 목적으로 한 벌목재 등 사용목적에 따 라, 전목생산 단목생산 등의 생산시스템에 따라, 생산 시스템의 기계화 정도 및 생산량의 종류에 따라 그리 고 산림 바이오매스의 생산지와 사용지간의 운송거리 에 따라 많은 차이가 나타날 수 있다[30].

따라서, 본 연구에서는 연료림인 리기다소나무를 대상으로 전목생산, 전간재생산과 같은 생산시스템의 종류 그리고 생산지와 사용지간의 운송거리에 따라 수행한 공정분석 및 시험결과를 바탕으로 최적의 생 산시스템을 개발하고 생산비용 및 공급가격을 분석하 고자 한다[5,11].

\section{2-1. 생산비용의 산출기준}

예정가격 작성기준』 에 따르면 공사원가는 크게 노무비, 재료비, 경비, 일반관리비로 분류할 수 있다. 노무비에는 직접노무비와 간접노무비로, 재료비는 직 접재료비와 간접재료비로, 경비는 기계경비, 보험료 등으로 분류할 수 있다[30].

(1) 노무비

노무비는 벌목, 조재와 같이 기계톱을 사용하는 인원과 쵸킹수와 같이 현지에서 채용한 인원의 경 우는 지역의 현실 노임단가를 적용하였으며, 노무 비의 산출기준은 건설공사 표준품셈에서 제시된 data를 적용하였다[30]. 
(2) 재료비

재료비 중의 원재료는 해당사항이 없으며, 본 연 구에서 사용하고 있는 장비들의 운전에 필요한 주 연료와 잡재료를 반영하였다. 주연료는 제조자 또 는 장비대여 업체에서 제시하는 값을 사용하였으 며, 제시되지 않는 장비에 한해서는 건설공사 표준 품셈에서 제시하고 있는 값을 사용하였다. 또한 잡 재료비는 건설공사 표준품셈에서 제시된 data를 활 용하였다[24.27,30].

(3) 경 비

경비 중 기계경비는 감가상각비, 정비비, 관리비 로 구분이 되며 각각 공사표준품셈에 제시된 손료 를 활용하였다. 단 파쇄기는 공사표준품셈을 적용 하지 않고 해외 파쇄비용 산출 자료를 인용하였다. 또한 고성능임업기계 임차의 경우 임업기계지원센 터의 임차비의 단가산정 부분에 감가상각비의 비 계상으로 임차비에 감가상각비를 산정하여 기계경 비를 산출하였다[30].

\section{2-2. 생산비용의 산출}

(1) 임지의 경사에 따른 표준단가 산출

파장의 시험 필지에서의 생산량을 이용하여 Table 1에서 보는 바와 같이 임지의 경사도를 완 (15이이), 중 $\left(15 \sim 30^{\circ}\right)$, 급( $30^{\circ}$ 이상)으로 구분하 여 투입장비에 대한 표준단가를 산출하였다[30].

(2) 파쇄공정에 따른 표준단가 산출

II장의 5 개 종류의 파쇄기를 활용한 시험결과에 서 얻은 파쇄량, 파쇄시간을 기본으로 하여 파쇄 공정에서의 원가를 산출하면 Disc Type $\left(40^{\circ}\right)$ 인 장비가 7,736원/ton으로 생산원가 측면에서 가장 우수하였으며, Grinder(수평)가 19,747원/ton으로 가장 높은 결과를 얻었다.

(3) 운송공정에 따른 표준단가 산출

II 장에서 얻은 data를 활용하여 경산 서대구간 의 운송원가(운송거리 약 $46 \mathrm{~km})$ 와 동일한 조건일 때 거리별 운송원가를 산정하였다.

\section{2-3. 조정을 통한 표준단가 산출}

(1) 기능 인력의 작업숙련도

본 연구에서 공정조사에 참여한 기능 인력의 작 업효율성을 객관적인 지표로 판단하기 위해 작업 공정을 분석하여 기능인력 숙련도 기준표를 적용
하여 생산비용에 적용하였다. 다만 벌목공정의 숙 련도는 작업자의 경력이 5 년 10 년 정도의 숙련자 이므로 공정분석을 생략하고, 스윙야더 등 작업자 의 경력이 5 년 이하의 작업자에 대하여 작업지연 사유 등 작업공정 분석 후 표준 작업량을 추정하 여 현 단계의 숙련도를 분석하였다[6,30].

\section{2-4. 추가공정별 표준단가 산출}

산주보상금(임목대금)

본 연구에서 4 개 지역의 사유림 대상지를 선정하 여 조사대상 필지별로 발생한 임목에 대해 진안군 일대 리기다소나무림의 임목 거래가격을 기준으로 산주에게 임목대금을 Table 2와 같이 지급하였다 [27].

공정조사 대상 4 개 필지의 면적은 $8.68 \mathrm{ha}$ 로 임목 축적은 $904.1 \mathrm{~m}^{3}$ 이다. 총 산주보상금액 11,900 천원을 지급하여 산주보상금은 13,162 원 $/ \mathrm{m}^{3}(\mathrm{ton})$ 정도이다.

\section{2-4. 추가공정별 표준단가 산출}

현재 진안군 인근에서 제지공장에 납품되고 있는 자료를 참고하여 다음과 같이 단가를 산정해 보았 다. 단목 운송차량은 5 톤 트럭을 개조한 차량으로 대당 $18 \sim 20$ ton 가량의 단목을 운송하고 있는 것 으로 조사되었으며, 평균 연비는 약 $3.3 \mathrm{~km} / \mathrm{L}$ 로 조 사되었다. 노무비, 경비는 대한건설협회와 건설공 사품셈을 인용하였다. 상차를 $0.3 \mathrm{~m} 3$ 의 우드그랩으 로 작업을 하였기 때문에 상차시간이 많이 소요되 었다[5,30].

\section{2-6. 리기다소나무의 중량측정}

(1) 리기다소나무의 재적 대비 중량측정 리기다소나무의 전목 및 전간재의 재적 대비 중 량에 대한 시험은 2 차 시험임지인 물곡리 산 54 번 지에서 이루어졌으며, 전목 73 본을 시료로 사용하 였다. 시험 방법은 리기다소나무를 전목집재하여 수고와 경급을 측정한 후 로드셀을 이용하여 중량 을 측정한 후 기계톱을 사용하여 가지치기작업을 시행하고 전간재 상태의 시료를 로드셀로 중량을 측정하여 각 시료의 재적별 전목 및 전간재의 무게 의 변위를 측정하였다. 시료의 평균직경 $20 \mathrm{~cm}$, 평 균수고 $16 \mathrm{~m}$, 평균재적은 $0.2527 \mathrm{~m}^{3}$, 평균무게는 전 목의 경우 평균 $247.6 \mathrm{~kg}$ 으로 재적대비 무게비율이 
Table 1. 전목작업 공정별 표준단가 산출

\begin{tabular}{|c|c|c|c|c|c|c|c|c|}
\hline 공 정 & 적용기계 & 작업경력 & 숙련도 & 경사 & $\begin{array}{c}\text { 작업량 } \\
\text { (m,ton/일) }\end{array}$ & 생산비용 & 기업이윤 & 합 계 \\
\hline \multirow{3}{*}{ 작업로 } & \multirow{3}{*}{ 굴삭기 } & \multirow{3}{*}{ 3년 } & \multirow{3}{*}{1.0} & 완 & 248.3 & 931 & 93 & 1,024 \\
\hline & & & & 중 & 214.3 & 1,078 & 108 & 1,186 \\
\hline & & & & 급 & 98.4 & 2,347 & 235 & 2,582 \\
\hline \multirow{3}{*}{ 벌 목 } & \multirow{3}{*}{ 기계톱 } & \multirow{3}{*}{ 3 10년 } & \multirow{3}{*}{1.0} & 완 & 23.73 & 1,762 & 176 & 1,939 \\
\hline & & & & 중 & 20.77 & 1,938 & 194 & 2,132 \\
\hline & & & & 급 & 20.66 & 5,714 & 571 & 6,285 \\
\hline \multirow{5}{*}{ 집 재 } & \multirow{3}{*}{ 스윙야더 } & \multirow{3}{*}{$\begin{array}{l}\text { 1년 } \\
\text { 미만 }\end{array}$} & 0.96 & 완 & 23.73 & 15,731 & 1,573 & 17,305 \\
\hline & & & 0.88 & 중 & 20.77 & 17,971 & 1,797 & 19,768 \\
\hline & & & 0.81 & 급 & 20.66 & 18,069 & 1,807 & 19,876 \\
\hline & \multirow{2}{*}{ 타워야더 } & \multirow{2}{*}{ 3년 } & 0.92 & 중 & 12.71 & 31,552 & 3,155 & 34,707 \\
\hline & & & 0.88 & 급 & 11.81 & 33,973 & 3,397 & 37,370 \\
\hline \multirow{3}{*}{ 소운반 } & \multirow{3}{*}{ 그라플스키더 } & \multirow{3}{*}{$\begin{array}{l}\text { 1년 } \\
\text { 미만 }\end{array}$} & 0.94 & 완 & 45.38 & 3,648 & 365 & 4,013 \\
\hline & & & 1.0 & 중 & 10.99 & 15,059 & 1,506 & 16,565 \\
\hline & & & 1.0 & 급 & 7.85 & 21,082 & 2,108 & 23,191 \\
\hline 조재 & 기계톱 & 3-10년 & 1.0 & - & 15.58 & 6,067 & 607 & 6,673 \\
\hline \multirow{2}{*}{ 파쇄 } & Disc & 5년이상 & 1.0 & - & - & 7,736 & 774 & 8,510 \\
\hline & Grinder & 5년이상 & 1.0 & - & - & 10,472 & 1,047 & 11,519 \\
\hline chip운반 & $50 \mathrm{~m} 3$ & 5 이상 & 1.0 & - & - & 23,131 & 2,313 & 25,444 \\
\hline 단목운반 & 5ton개량 & 5년이상 & 1.0 & - & - & 14,485 & 1,449 & 15,934 \\
\hline
\end{tabular}

Table 2. 전간재 작업공정별 표준단가 산출

단위 : 원/ton

\begin{tabular}{|c|c|c|c|c|c|c|c|c|}
\hline 공 정 & 적용기계 & 작업경력 & 숙련도 & 경사 & $\begin{array}{c}\text { 작업량 } \\
\text { (m,ton/일) }\end{array}$ & 생산비용 & 기업이윤 & 합 계 \\
\hline \multirow{3}{*}{ 작업로 } & \multirow{3}{*}{ 굴삭기 } & \multirow{3}{*}{ 3년 } & \multirow{3}{*}{1.0} & 완 & 248.3 & 931 & 93 & 1,024 \\
\hline & & & & 중 & 214.3 & 1,078 & 108 & 1,186 \\
\hline & & & & 급 & 98.4 & 2,347 & 235 & 2,582 \\
\hline \multirow{3}{*}{ 벌 목 } & \multirow{3}{*}{ 기계톱 } & \multirow{3}{*}{ 3 10년 } & \multirow{3}{*}{1.0} & 완 & 11.59 & 7,901 & 790 & 8,691 \\
\hline & & & & 중 & 8.60 & 10,654 & 1,065 & 11,719 \\
\hline & & & & 급 & 4.59 & 19,967 & 1,997 & 21,964 \\
\hline \multirow{8}{*}{ 집 재 } & \multirow{3}{*}{ 스윙야더 } & \multirow{3}{*}{ 1년 미만 } & 0.91 & 완 & 22.40 & 15,731 & 1,573 & 17,305 \\
\hline & & & 0.80 & 중 & 19.15 & 17,971 & 1,797 & 19,768 \\
\hline & & & 0.81 & 급 & 18.44 & 18,069 & 1,807 & 19,876 \\
\hline & \multirow{2}{*}{ 타워야더 } & \multirow{2}{*}{ 3년 } & 0.81 & 중 & 11.34 & 37,190 & 3,719 & 40,909 \\
\hline & & & 0.85 & 급 & 9.47 & 44,531 & 4,453 & 48,984 \\
\hline & \multirow{3}{*}{$\begin{array}{l}\text { 파미 } \\
\text { 윈치 }\end{array}$} & \multirow{3}{*}{ 3년 } & 0.91 & 완 & 15.65 & 21,050 & 2,105 & 23,155 \\
\hline & & & 0.89 & 중 & 12.35 & 26,687 & 2,669 & 29,356 \\
\hline & & & 0.81 & 급 & 11.60 & 28,406 & 2,841 & 31,247 \\
\hline \multirow{3}{*}{ 소운반 } & \multirow{3}{*}{$\begin{array}{l}\text { 그라플 } \\
\text { 스키더 }\end{array}$} & \multirow{3}{*}{ 1년 미만 } & 0.75 & 완 & 54.18 & 3,055 & 306 & 3,361 \\
\hline & & & 0.92 & 중 & 17.19 & 9,628 & 963 & 10,591 \\
\hline & & & 1.0 & 급 & 13.03 & 12,701 & 1,270 & 13,971 \\
\hline 조재 & 기계톱 & 3-10년 & 1.0 & - & 38.78 & 2,438 & 244 & 2,682 \\
\hline \multirow{2}{*}{ 파쇄 } & Disc & 5년이상 & 1.0 & - & - & 7,736 & 774 & 8,510 \\
\hline & Grinder & 5년이상 & 1.0 & - & - & 10,472 & 1,047 & 11,519 \\
\hline chip운반 & $50 \mathrm{~m} 3$ & 5년 이상 & 1.0 & - & - & 23,131 & 2,313 & 25,444 \\
\hline 단목운반 & 5ton개량 & 5년 이상 & 1.0 & - & - & 14,485 & 1,449 & 15,934 \\
\hline
\end{tabular}




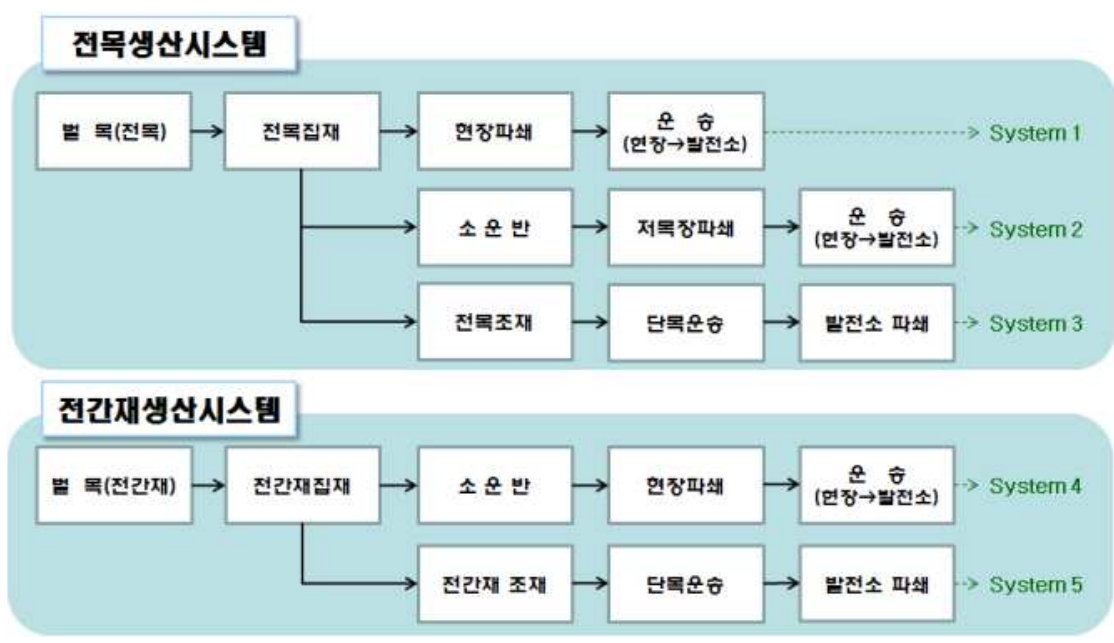

Fig. 1. 전목 집재장 Chipping 작업시스템
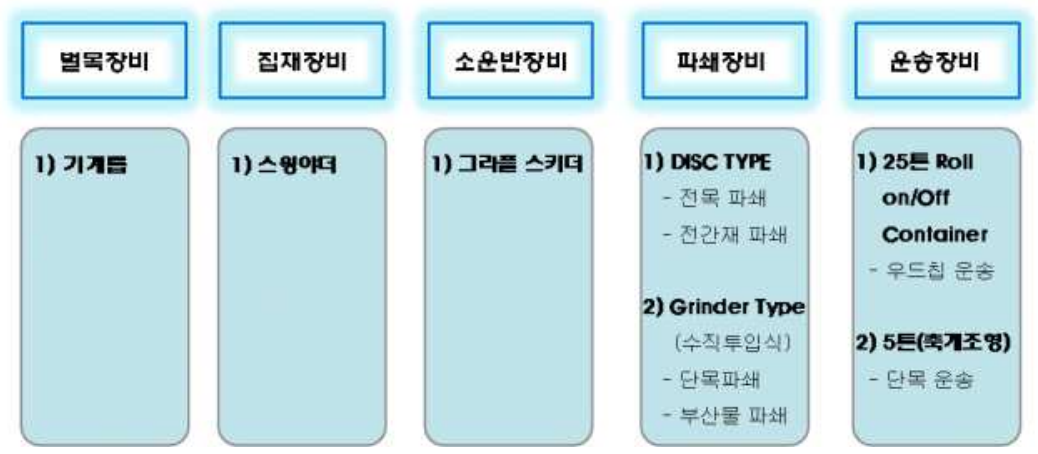

Fig. 2. 현 기술수준에서의 추천장비

평균 0.98 , 전간재의 경우 평균 $211.4 \mathrm{~kg}$ 으로 재적 대비 무게비율이 평균 0.83 으로 조사 되었다. 또한 전목의 경우 중량이 평균 $247.6 \mathrm{~kg}$ 에 대비 전간재 중량은 평균 $211.4 \mathrm{~kg}$ 으로 지조량은 평균 $36.2 \mathrm{~kg}$ 으 로 조사되었다.

\section{2-7. 최종 표준단가 산출}

앞에서 구한 임지 경사도에 따른 장비별 표준단가 에 기능 인력의 숙련도를 반영하고 추가적으로 산정 한 조재비용, 단목 운송비용 및 비중을 적용하여 다 음과 같이 최종 표준생산단가를 산출하였다 $[6,24]$.

\section{3. 생산시스템별 연료 생산비용 산정}

\section{3-1. 현 기술수준하의 공급단가}

앞에서 각 공정분석에 따른 장비별 연료생산 표준 단가를 산정하였다. 리기다소나무를 에너지연료로 활용하기 위하여 현 기술수준에서의 경제성 있는 생
산시스템을 제안하고 앞서 산정된 장비별 표준단가를 이용하여 각 생산시스템별 생산비용을 산정하였다 $[11,20,29,30]$.

생산시스템은 크게는 집재의 형태에 따라 전목 상 태 또는 전간재 상태로 구분하였으며, 세부적으로는 생산임지에 대한 차량의 접근성에 따라 구분하여 다 음과 같이 5 개의 시스템으로 구성하였다 $[4,7,10]$.

Fig. 1 의 시스템에 적용되는 장비는 각 공정별 공정원가가 우수한 장비가 추천되며, Fig 2 와 같다.

(1) 전목 작업시스템

전목 작업시스템은 벌목과정이 전간재 및 단목 방식에 비해 단공정 작업으로 가지치기 및 토막내기 (조재) 작업공정이 생략된 작업시스템으로서, 기존 생산시스템에서는 버려지던 지조물까지도 전량 에 너지로 활용할 수 있기 때문에, 생산성 및 효율성과 벌목 작업의 안정성이 전간재 및 단목에 비해 높은 시스템이다. 임지의 차량접근성에 따라 파쇄위치가 


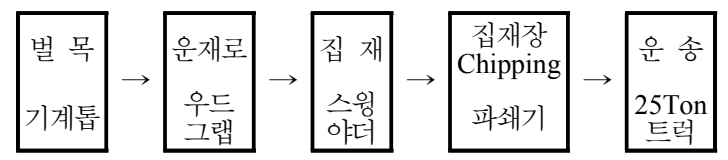

Fig. 3. 전목 집재장 작업시스템
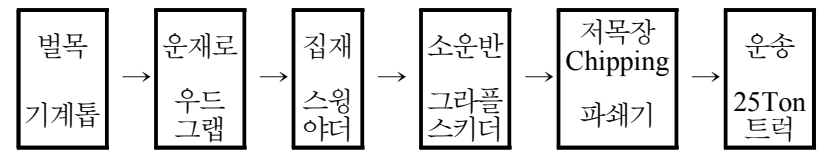

Fig. 4. 전목 저목장 작업시스템

Table 3. 생산비용 산출

단위 : 원/ton

\begin{tabular}{|c|c|c|c|c|c|c|}
\hline 공정구분 & 적용 기계 & 경사도 & 작업량[ton/일] & 생산비용 & 기업이윤 & 합 계 \\
\hline \multirow{3}{*}{ 벌 목 } & \multirow{3}{*}{ 기계톱 } & 완 & 51.98 & 1,762 & 176 & \begin{tabular}{c|}
1,938 \\
\end{tabular} \\
\hline & & 중 & 47.27 & 1,938 & 194 & 2,132 \\
\hline & & 급 & 16.03 & 5,714 & 571 & 6,285 \\
\hline \multirow{3}{*}{ 집 재 } & \multirow{3}{*}{ 스윙야더 } & 완 & 23.73 & 15,731 & 1,573 & 17,304 \\
\hline & & 중 & 20.77 & 17,971 & 1,797 & 19,768 \\
\hline & & 급 & 20.66 & 18,069 & 1,807 & 19,876 \\
\hline Chipping & DISC & - & - & 7,736 & 774 & 8,510 \\
\hline Chip운송 & $50 \mathrm{~m} 3$ & - & - & 23,131 & 2,313 & 25,444 \\
\hline \multirow{3}{*}{\multicolumn{2}{|c|}{ 계 }} & 완 & - & 48,360 & 4,836 & 53,196 \\
\hline & & 중 & - & 50,776 & 5,078 & 55,854 \\
\hline & & 급 & - & 54,650 & 5,465 & 60,115 \\
\hline
\end{tabular}

결정되어 집재장 Chipping작업시스템, 저목장(토장) Chipping작업시스템과 발전소 Chipping작업시스템 으로 분류하였다[7].

(1) System 1 : 전목 집재장 작업시스템

(가) 시스템설명

전목 형태로 벌목과정이 수행되고 집재장에 스윙야더를 이용한 간선집재로 집재장에 전목 이 집재되고, 집재된 전목을 이동식 파쇄기를 이용하여 집재장에서 파쇄한 후 운송트럭에 직접상차 또는 굴삭기를 이용한 상차과정 후 발전소로 운송되는 시스템이다[7].

(나) 전제조건

대형 Chip 운송차량이 집재장까지 접근 가 능할 수 있도록 지방도로와 근접해 있거나, 지방도로와 집재장을 잇는 임도가 대형차량 의 운행이 가능한 조건

(다) 장점

벌목과정에서 가지치기 및 조재(토막내기) 의 공정이 없어짐으로 인해 전간재 대비 $300 \%$ 의 작업 효율을 높일 수 있으며, 또한 전간재 및 단목 집재 대비 $15 \%$ 정도 지엽발 생량을 수집하므로 물질 활용도를 높일 수 있으며, 지조물 방치로 인한 산림화재 발생 위험을 줄이는 효과가 있다.
(라) 생산원가 산출

경사도에 따른 생산원가는 Table 3 과 같다 $[27,30]$.

(2) System 2 : 전목 저목장 작업시스템

(가) 시스템설명

전목 형태로 벌목과정이 수행되고 집재장에서 스윙야더를 이용한 간선집재로 집재장에 전목 이 집재되고, 집재된 전목을 그라플 스키더로 저목장까지 운반한 후 이동식 파쇄기를 이용하 여 저목장에서 파쇄하여 운송트럭에 직접상차 또는 굴삭기를 이용한 상차과정 후 발전소로 운 송되는 시스템이다[7].

(나) 전제조건

집재장까지 Chip 운반차량의 진입이 어려운 경 우로 Chip 운반차량이 진입할 수 있는 임도변 이나 지방도변에 저목장의 개설이 가능한 공터 가 있어야 한다.

(다) 장점

전목 상태로 활용됨으로써 그 장점은 System 1 과 같다.

(라) 생산원가 산출

경사도에 따른 생산원가는 Table 4와 같다 $[27,30]$.

(3) System3 : 전목 발전소 작업시스템 
Table 4. 생산비용 산출

\begin{tabular}{|c|c|c|c|c|c|c|}
\hline 공정구분 & 적용 기계 & 경사도 & 작업량[ton/일] & 생산비용 & 기업이윤 & 합 계 \\
\hline \multirow{3}{*}{ 벌 목 } & \multirow{3}{*}{ 기계톱 } & 완 & 52.0 & 1,762 & 176 & 1,938 \\
\hline & & 중 & 47.3 & 1,938 & 194 & 2,132 \\
\hline & & 급 & 16.0 & 5,714 & 571 & 6,285 \\
\hline \multirow{3}{*}{ 집 재 } & \multirow{3}{*}{ 스윙야더 } & 완 & 23.7 & 15,731 & 1,573 & 17,304 \\
\hline & & 중 & 20.8 & 17,971 & 1,797 & 19,768 \\
\hline & & 급 & 20.7 & 18,069 & 1,807 & 19,876 \\
\hline 소운반 & 그라플 스키더 & - & 28.2 & 9,353 & 935 & 10,288 \\
\hline Chipping & DISC & - & - & 7,736 & 774 & 10,288 \\
\hline Chip운송 & $50 \mathrm{~m} 3$ & - & - & 23,131 & 2,313 & 8,510 \\
\hline \multirow{3}{*}{\multicolumn{2}{|c|}{ ㅖㅖ }} & 완 & - & 57,713 & 5,771 & 63,484 \\
\hline & & 중 & - & 60,129 & 6,013 & 66,142 \\
\hline & & 급 & - & 64,003 & 6,400 & 70,403 \\
\hline
\end{tabular}

Table 5. 생산비용 산출

단위 : 원/ton

\begin{tabular}{|c|c|c|c|c|c|c|}
\hline 공정구분 & 적용 기계 & 경사도 & 작업량[ton/일] & 생산비용 & 기업이윤 & 합 계 \\
\hline \multirow{3}{*}{ 벌 목 } & \multirow{3}{*}{ 기계톱 } & 완 & 52.0 & $1,1,762$ & 176 & 1,922 \\
\hline & & 중 & 47.3 & 1,938 & 194 & 2,113 \\
\hline & & 급 & 16.0 & 5,714 & 571 & 6,229 \\
\hline \multirow{3}{*}{ 집 재 } & \multirow{3}{*}{ 스윙야더 } & 완 & 23.7 & 15,731 & 1,573 & 17,332 \\
\hline & & 중 & 20.8 & 17,971 & 1,797 & 20,056 \\
\hline & & 급 & 20.7 & 18,069 & 1,807 & 20,621 \\
\hline 조 재 & 기계톱 & - & 15.6 & 2,438 & 244 & 2,682 \\
\hline 단목운반 & 5ton개량 & - & - & 14,485 & 1,449 & 15,934 \\
\hline Chipping & Grinder & - & - & 10,472 & 1,047 & 11,519 \\
\hline \multirow{3}{*}{\multicolumn{2}{|c|}{ 계 }} & 완 & - & 44,888 & 4,489 & 49,377 \\
\hline & & 중 & - & 47,304 & 4,731 & 52,035 \\
\hline & & 급 & - & 51,178 & 5,118 & 56,296 \\
\hline
\end{tabular}

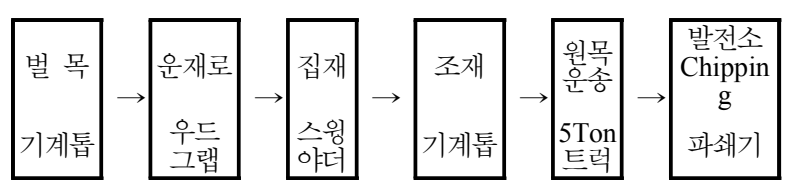

Fig. 5. 전목 발전소 작업시스템

\section{(가) 시스템설명}

전목 형태로 벌목과정이 이루어지고 집재장에서 스윙야더를 이용한 간선집재로 집재장에 전목을 집재하며, 집재된 전목을 기계톱을 이용하여 조 재를 한 후 5 톤트럭(축개조형)을 이용하여 발전 소로 운송하여 파쇄기를 이용 파쇄한 후 직접 발 전소로 투입하는 시스템이다. 펄프용으로 공급 하는 단목생산 시스템과는 달리, 잔가지는 조재 하지 않고 굵은 가지 위주로 가지치기 작업을 수 행한다[4,7].

(나) 전제조건
임도나 지방도로에서 집재장까지 이어지는 작업 로는 5ton트럭의 운행이 가능해야 하며, 발전소 내 파쇄공정 및 야적을 위한 충분한 공간이 확보 되어야 한다.

(다) 장점

전목상태로 활용됨으로 인한 장점은 System 1, 2 와 같다. 5ton트럭이 진입이 가능하면 적용할 수 있으므로 적용 가능한 임지가 많다.

(라) 생산원가 산출

경사도에 따른 생산원가는 Table 5와 같다 $[27,30]$.

(2) 전간재 작업시스템

전간재 작업시스템은 벌목 후 단목을 실시하지 않고 지조물만을 조재하여 벌목지역에다 방치하기 때 문에 물질 이용도는 전목시스템에 비해 낮으나 토막 내기 작업공정이 제외가 됨으로 생산성은 단목 시스 


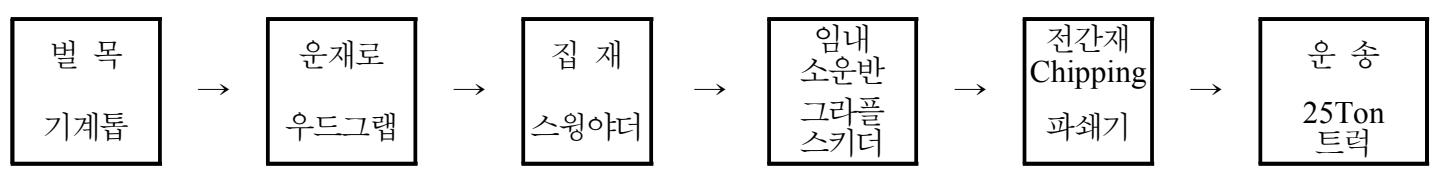

Fig. 6. 전간재 저목장 작업시스템

Table 6. 생산비용 산출

단위 : 원/ton

\begin{tabular}{|c|c|c|c|c|c|c|}
\hline 공정구분 & 적용 기계 & 경사도 & 작업량[ton/일] & 생산비용 & 기업이윤 & 합 계 \\
\hline \multirow{3}{*}{ 벌 목 } & \multirow{3}{*}{ 기계톱 } & 완 & 11.6 & $7,7,901$ & 790 & 8,691 \\
\hline & & 중 & 8.6 & 10,654 & 1,065 & 11,719 \\
\hline & & 급 & 4.6 & 19,967 & 1,997 & 21,964 \\
\hline \multirow{3}{*}{ 집 재 } & \multirow{3}{*}{ 스윙야더 } & 완 & 22.4 & 16,669 & 1,667 & 18,336 \\
\hline & & 중 & 19.2 & 19,495 & 1,950 & 21,445 \\
\hline & & 급 & 18.4 & 20,246 & 2,025 & 22,271 \\
\hline 소운반 & 그라플 스키더 & - & 36.0 & 6,342 & 634 & 6,976 \\
\hline Chipping & DISC & - & - & 7,736 & 774 & 8,510 \\
\hline Chip운송 & $50 \mathrm{~m} 3$ & - & - & 23,131 & 2,313 & 25,444 \\
\hline \multirow{3}{*}{\multicolumn{2}{|c|}{ 계 }} & 완 & - & 61,779 & 6,178 & 67,957 \\
\hline & & 중 & - & 67,358 & 6,736 & 74,094 \\
\hline & & 급 & - & 77,422 & 7,743 & 85,165 \\
\hline
\end{tabular}

템에 비해서는 우수한 시스템이다. 전간재 작업시스 템 역시 차량의 임지 접근성에 따라 저목장 작업시스 템과 발전소 작업시스템으로 구분할 수 있다[7].

(1) System 4 : 전간재 저목장 작업 시스템 (가) 시스템설명

전간재 형태로 벌목을 수행하고 집재장에서 스 윙야더를 이용한 간선집재로 집재장에 집재를 하게 되며, 집재된 전간재를 그라플스키더를 이 용하여 저목장까지 운반한 후, 이동식 파쇄기를 이용하여 저목장에서 전간재를 파쇄하여 운송트 럭에 직접상차 또는 굴삭기를 이용한 상차과정 후 발전소로 운송하는 시스템이다[7].

(나) 전제조건

집재장까지 Chip 운반차량의 진입이 어려운 경 우, Chip 운반차량이 진입할 수 있는 임도변이나 지방도변에 저목장 개설이 가능한 공터가 있어야 한다.

(다) 장점

단목 방식에 비해 생산성이 높다.

(라) 생산원가 산출
경사도에 따른 생산원가는 Table 6과 같다 [27,30].

(2) System 5 : 전간재 발전소 작업 시스템

(가) 시스템설명

전간재 형태로 벌목과정이 이루어지고 집재장에 서 스윙야더를 이용한 간선집재로 집재장에 전간 재 형태로 집재를 하며, 집재된 전간재를 기계톱 을 이용하여 조재를 한 후 5 톤트럭(축개조형)을 이용하여 발전소로 운송하여 파쇄기를 이용 파쇄 한 후 직접 발전소로 투입하는 시스템이다[7].

(나) 전제조건

집재장까지 Chip 운반차량의 진입이 어려운 경 우, Chip 운반차량이 진입할 수 있는 임도변이나 지방도변에 저목장 개설이 가능한 공터가 있어야 한다.

(다) 장점

5ton트럭의 진입이 가능하면 적용할 수 있으므 로 적용 가능한 임지가 많다.

(라) 생산원가 산출 경사도에 따른 생산원가는 Table 7과 같다.

(3) 운재로 개설 운재로 개설은 우리나라 임지의 지형적인 특성 


$$
\begin{array}{|c}
\text { 벌 목 } \\
\text { 기계톱 }
\end{array} \rightarrow \begin{gathered}
\text { 운재로 } \\
\text { 우드그랩 }
\end{gathered} \rightarrow \begin{gathered}
\text { 집 재 } \\
\text { 스윙야더 }
\end{gathered} \rightarrow \begin{gathered}
\text { 조 재 } \\
\text { 기계톱 }
\end{gathered} \rightarrow \begin{gathered}
\text { 원목운송 } \\
5 \text { Ton트럭 }
\end{gathered} \rightarrow \begin{gathered}
\begin{array}{c}
\text { 발전소 } \\
\text { Chipping } \\
\text { 파쇄기 }
\end{array} \\
\hline
\end{gathered}
$$

Fig. 7. 전간재 저목장 작업시스템

Table 7. 생산비용 산출

단위 : 원/ton

\begin{tabular}{|c|c|c|c|c|c|c|}
\hline 공정구분 & 적용 기계 & 경사도 & 작업량[ton/일] & 생산비용 & 기업이윤 & 합 계 \\
\hline \multirow{3}{*}{ 벌 목 } & \multirow{3}{*}{ 기계톱 } & 완 & 11.6 & 7,901 & 790 & 8,691 \\
\hline & & 중 & 8.6 & 10,654 & 1,065 & 11,719 \\
\hline & & 급 & 4.6 & 19,967 & 1,997 & 21,964 \\
\hline \multirow{3}{*}{ 집 재 } & \multirow{3}{*}{ 스윙야더 } & 완 & 22.4 & 16,669 & 1,667 & 18,336 \\
\hline & & 중 & 19.2 & 19,495 & 1,950 & 21,445 \\
\hline & & 급 & 18.4 & 20,246 & 2,025 & 22,271 \\
\hline 조 재 & 기계톱 & - & 38.8 & 2,438 & 244 & 2,682 \\
\hline 단목운반 & 5ton개량 & - & - & 14,485 & 1,449 & 15,934 \\
\hline Chipping & Grinder & - & - & 10,472 & 1,047 & 11,519 \\
\hline \multirow{3}{*}{\multicolumn{2}{|c|}{ 계 }} & 완 & - & 51,965 & 5,197 & 57,162 \\
\hline & & 중 & - & 57,544 & 5,755 & 63,299 \\
\hline & & 급 & - & 67,608 & 6,762 & 74,370 \\
\hline
\end{tabular}

Table 8. 운재로 개설비용 산출

\begin{tabular}{|c|c|c|c|c|c|c|}
\hline 공정구분 & 적용 기계 & 경사도 & 작업량[ton/일] & 생산비용 & 기업이윤 & 합 계 \\
\hline \multirow{3}{*}{ 운재로 } & \multirow{3}{*}{ 굴삭기 } & 완 & 248.3 & 931 & 93 & 1,024 \\
\hline & & 중 & 214.3 & 1,078 & 108 & 1,186 \\
\hline & & 급 & 98.4 & 2,347 & 235 & 2,582 \\
\hline
\end{tabular}

Table 9. 열 전용시설 경제성분석 조건

\begin{tabular}{|c|c|c|}
\hline 항 목 & 기 준 & 비 고 \\
\hline 할 인 율 & $7 \%$ & \\
\hline 감가상각비 & 20년 균등 & \\
\hline 예적금 이자율 & $3.0 \%$ & \\
\hline 수선유지비 & $4 \%$ & 직접투자비 기준 \\
\hline 보험료요율(화재+기계) & $0.2 \%$ & 직접투자비 기준 \\
\hline 법인세 & $25.0 \%$ & 지방세 미포함 \\
\hline 일반관리비 & $3.00 \%$ & 매출액 기준 \\
\hline 제세 & $0.20 \%$ & 직접투자비+토지비 기준 \\
\hline 연료 발열량 & $2,700 \mathrm{kcal} / \mathrm{kg}$ & \\
\hline 전력 & 72.00 원/kwh & \\
\hline 공업용수 & 660 원/톤 & \\
\hline 증기특성 & 9bar, 포화온도 & \\
\hline \multirow{3}{*}{ 자금조달 } & 정책 자금 & $4.27 \%$ 이자, 8 년거치, 7 년상환 \\
\hline & 차입 & $7.2 \%$ 이자, 5년상환 \\
\hline & 운전율 & $70 \%$ \\
\hline 증기공급량 & 288,000 ton $/ y$ & 부하율 $80 \%$ 로 가정 \\
\hline 용수사용량 & 308,160 ton $/ y$ & \\
\hline 전력소모량 & $5,184 \mathrm{MWh}$ & \\
\hline 연료소비량 & 84,866 ton $/ \mathrm{y}$ & \\
\hline
\end{tabular}


으로 인하여 임지의 경사도, 접근성, 작업시스템, 임 업기계의 선택 등에 따라 운재로의 개설 필요도가 달 라질 수 있으므로 작업시스템별 생산비용산출 인자의 적용을 위해 임지의 경사도에 따라 운재로 개설비용 을 Table 8 과 같이 산출하였다.

\section{4. 리기다소나무의 에너지연료 활용을 위한} 경제성분석

본 장에서는 열 전용시설과 발전 전용시설의 투 자비와 예상효과를 비교 분석하여 그 사업이 투자 대 비 경제적 타당성을 가지는 가를 평가하며 그 평가방 법으로는 1) 내부수익률(IRR:Internal Ratio of Return) 2) 순현재가치(NPV:Net Present Value) 3) 편익비용분석(Benefit Cost Ratio) 4) 투자비회수기간 (Payback Period) 5) 발전원가분석의 5가지 지표를 적용 평가하였으며 이러한 경제성 분석결과와 앞에서 산출한 생산시스템별 생산단가의 산림 바이오매스를 연료로 사용할 경우의 경제성 여부를 비교 분석하였 다. 경제성 분석에 영향을 주는 인자인 에너지 공급 가격, 열(증기).전기 판매가격 및 이용률의 민감도에 따라 각각의 연료 한계가격을 산정하여 $\Pi 1$ 장에서 산 출한 생산시스템별 연료가격과 비교 분석하였다 $[9,12,20,29,60]$.

\section{1 열 전용시설}

본 연구에서 검토한 열 전용시설은 산업단지에 연중 열을 공급하는 시설로 $\mathrm{A}$ 사의 투자내역을 참조 하여 검토하였으며, 증기 판매가격과 이용률의 민감 도에 따른 연료 한계가격을 산정하였다.

(1) 분석조건

- 설비용량 : 증기 생산량 $80 \mathrm{ton} / \mathrm{h}(40 \mathrm{ton} / \mathrm{h} \times 2$ 기)

- 투자비 : 27,799,999천원

(2) 연료 한계가격 산정

(1) 증기 판매가격에 따른 연료 한계가격 산정(이 용률 $80 \%$ 일 때)

(2) 이용률 변화에 따른 연료 한계가격 산정(증기 판매가격 42,400원/ton일 때)

(3) 분 석

앞에서 산출한 system1 system3의 연료생산비 용 $(49,378$ 70,404원/ton, 전목의 경우)과 작업로 개설비용, 산주들에게 지불하는 임목대금( 13,162
Table 10. 화석연료에 따른 증기단가

\begin{tabular}{c|c|c}
\hline 항 목 & 증기단가 & 비 고 \\
\hline \hline $\mathrm{LNG}$ & 47,100 원/ton & \\
\hline $\mathrm{B}-\mathrm{C}(0.5)$ 유 & 59,300 원/ton & \\
\hline
\end{tabular}

원/ton) 등을 합한 공급가격과 연료 한계가격을 비교하면 Fig. 9와 같다[27,29,30].

열 전용 시설의 경우 증기(열)판매 단가, 이용률에 따라서 산림 바이오매스를 연료로 사용할 수 있는 한 계가격이 큰 차이가 있는 것으로 나타났다. 증기(열) 판매단가는 대부분이 수용가와의 계약에 의해 이루어 지며 일반적으로 원유, $\mathrm{LNG}$ 등의 화석연료의 가격에 따라 변동요금을 적용하고 있다. 하지만, 기존 화석연 료를 목질계 바이오매스 연료로 대체하는 경우 수용 가에서는 기존 증기(열) 생산단가보다 저렴한 가격으 로 증기(열)를 공급받으려 하기 때문에 증기(열) 판매 가격을 인상하는데 한계가 있으며, 이용률은 업체들 의 공장 가동율에 영향을 받기 때문에 호황기 또는 불황기냐에 따라 이용률에 차이를 보이게 된다.

증기가격과 이용률을 긍정적으로 반영할 경우에는 system1, system2 및 system3의 전목 생산시스템에 서 생산되는 연료는 모두 활용 가능하지만, 증기가격 과 이용률이 부정적인 경우 급경사에서 생산되는 산 림 바이오매스를 사용하기에는 일부 한계가 있는 것 으로 나타났다.

Table 10에서 보는 바와 같이 B-C유를 이용한 증 기 생산단가가 한계가격보다 높게 나타나기 때문에 $\mathrm{B}-\mathrm{C}$ 유를 사용하는 사용처에는 급경사시스템에서 생 산되는 산림 바이오매스 또한 사용이 가능하다.

- 연료가격만을 고려(효율 95\%)

- 증기조건 : $8 \mathrm{kgf} / \mathrm{cm} 2, \mathrm{a}$, 포화증기, 급수조건 : $120^{\circ} \mathrm{C}$

- 연료가격 : 790.37원/ Nm3 (삼천리 도시가스 경기 도지역 산업용 단가) 975.06원/L(SK에너지 '11년 11월 고 시단가)

- 발열량 : LNG $9550 \mathrm{kcal} / \mathrm{Nm} 3, \mathrm{~B}-\mathrm{C} 9350 \mathrm{kcal} / \mathrm{Nm} 3$

- 증기단가 $=($ 증기엔탈피 - 급수엔탈피 $) \times 1000 /$ 발열량 $\times$ 연료가격 


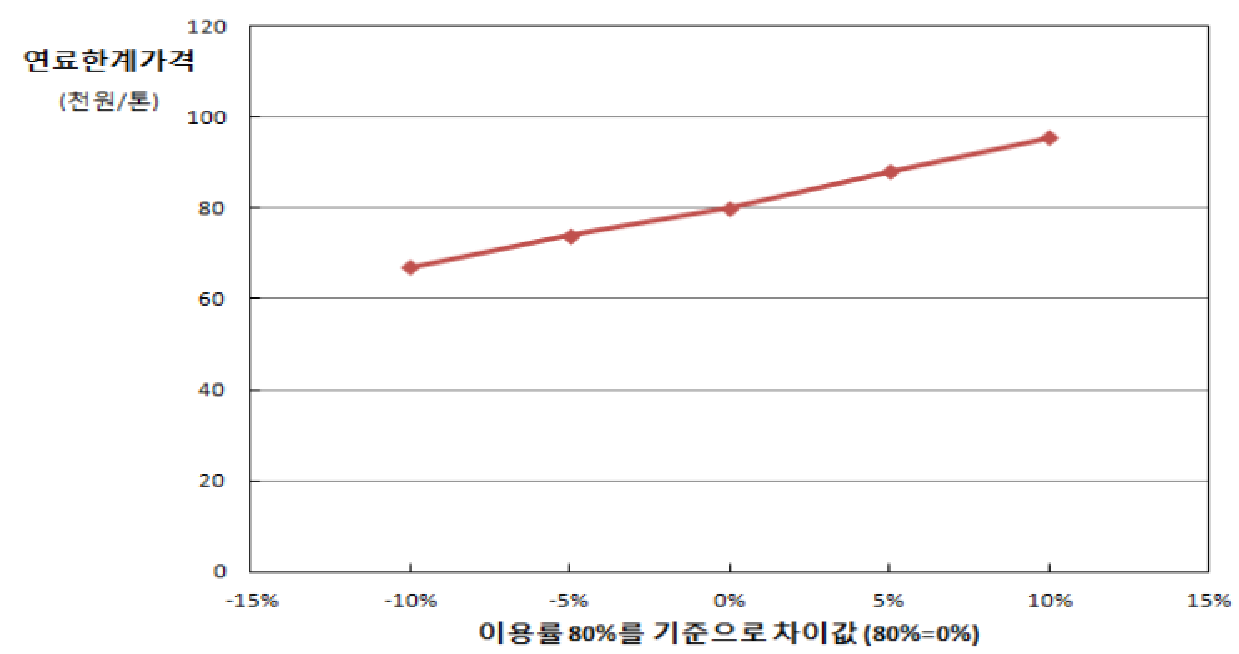

Fig. 8. 증기판매가격의 변화에 따른 연료 한계가격 변화

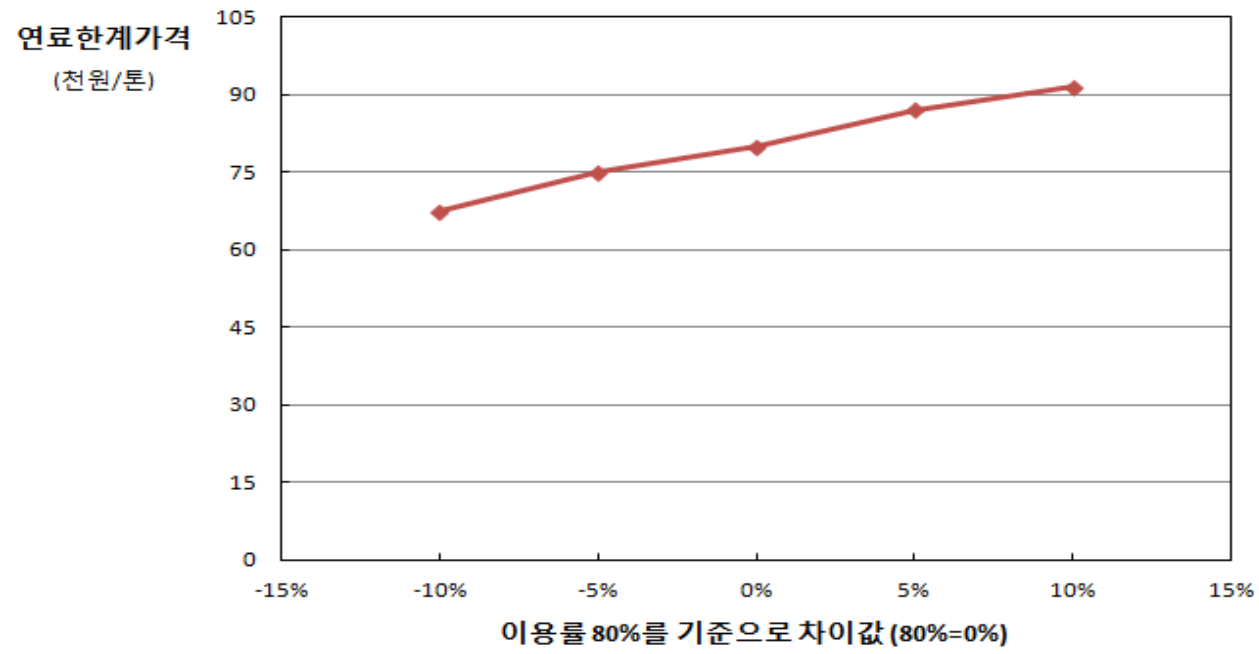

Fig. 9. 이용률 변화에 따른 연료 한계가격 변화

\section{2 발전 전용시설}

본 연구에서 검토한 발전 전용시설은 생산한 발전 전기를 전력거래소에 판매하는 시설로 $\mathrm{B}$ 사에서 발표 한 자료를 참조하여 검토하였으며, 전기 판매가격과 이용률의 민감도에 따른 연료 한계가격을 산정하였 다. 기본 전기 판매가격은 2011년도 SMP 평균가격 으로 산정하였다[29,30].

(1) 분석조건

- 설비용량 : $100 \mathrm{MW}(50 \mathrm{MW} \times 2$ 기 $)$

- 투자비 : 204,363,000천원
(2) 연료 한계가격 산정

(1) 전기 판매가격에 따른 연료 한계가격 산정(이용 률 $80 \%$ 일 때)

(2) 이용률 변화에 따른 연료 한계가격 산정(전기판 매가격 121.6원/kWh일 때)

(3) 분 석

연료 공급가격과 발전전용 시설에서의 연료 한 계가격을 비교하면 Fig. 12와 같다. 발전부분에 대한 경제성은 증기터빈발전 방식의 에너지 효율이 낮기 때문에 열 생산부문보다 연료 한계가격이 낮게 분포 된다[29]. 


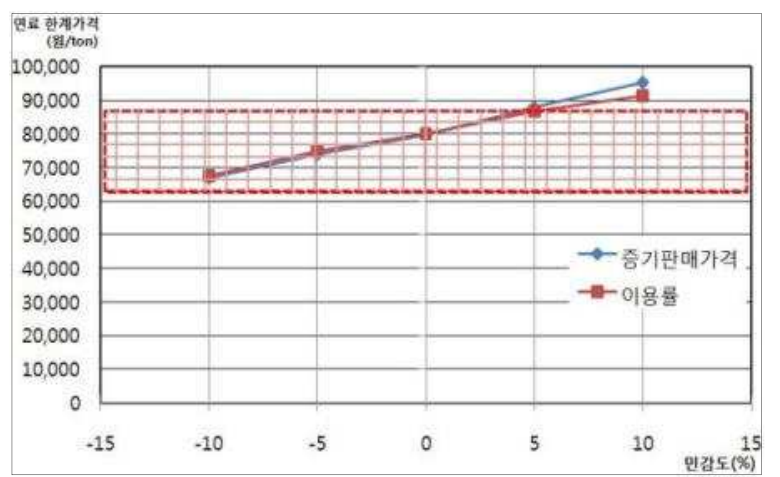

\begin{tabular}{c|c|c|c|c|c}
\hline \multirow{2}{*}{ 구 분 } & 경사도 & $\begin{array}{c}\text { 생산비용 } \\
\text { (원/톤) }\end{array}$ & $\begin{array}{c}\text { 작업로 } \\
\text { (원/m) }\end{array}$ & $\begin{array}{c}\text { 임목대금 } \\
\text { (원/톤) }\end{array}$ & $\begin{array}{c}\text { 공급단가 } \\
\text { (원/톤) }\end{array}$ \\
\hline \hline \multirow{3}{*}{ System1 } & 완 & 53,197 & 1,024 & & 67,383 \\
\cline { 2 - 4 } & 중 & 55,854 & 1,186 & & 70,202 \\
\cline { 2 - 4 } & 급 & 60,115 & 2,582 & & 75,859 \\
\hline \multirow{3}{*}{ System2 } & 완 & 63,486 & 1,024 & \multirow{4}{*}{13,162} & 77,672 \\
\cline { 2 - 4 } & 중 & 66,142 & 1,186 & 80,490 \\
\cline { 2 - 4 } & 급 & 70,404 & 2,582 & & 86,148 \\
\hline \multirow{3}{*}{ System3 } & 완 & 49,378 & 1,024 & & 63,563 \\
\cline { 2 - 4 } & 중 & 52,034 & 1,186 & & 66,382 \\
\cline { 2 - 4 } & 급 & 56,296 & 2,582 & & 72,040 \\
\hline
\end{tabular}

Fig. 10. 이용률 변화에 따른 연료 한계가격 변화

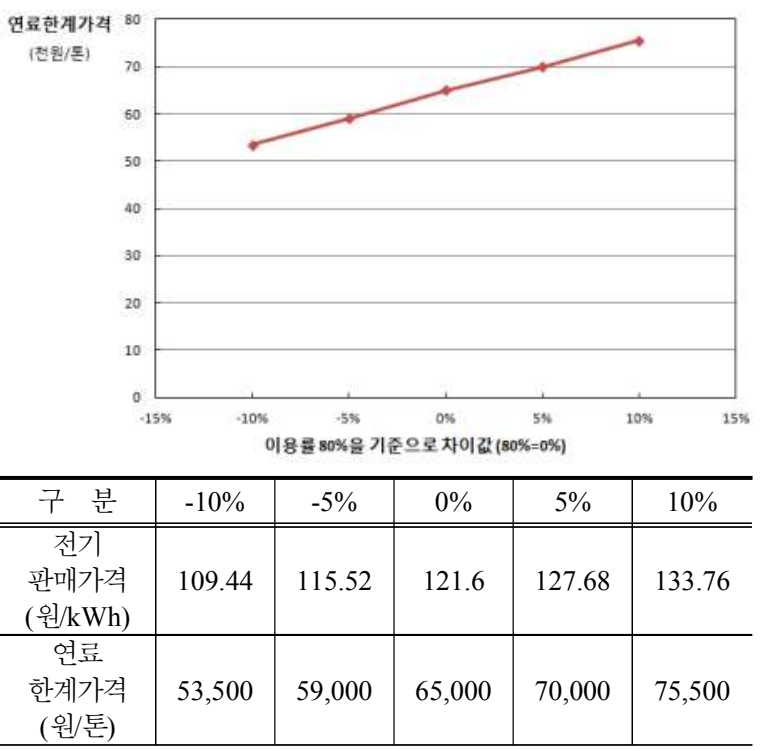

Fig. 11. 전기판매가격의 변화에 따른 연료 한계가격 변화

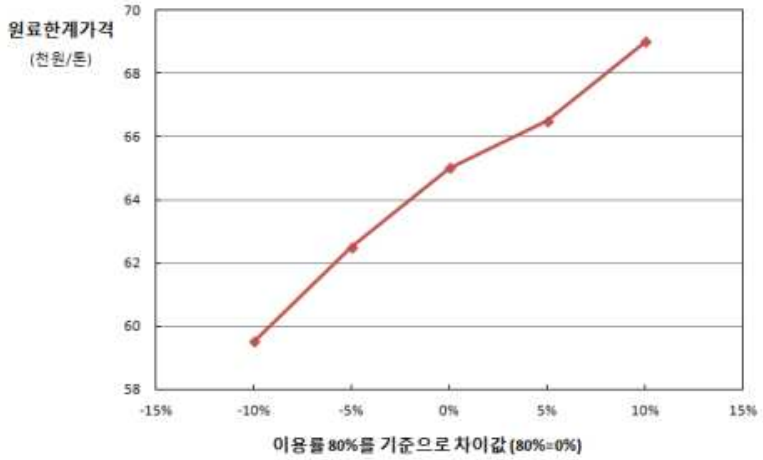

Fig. 12. 이용률의 변화에 따른 연료 한계가격 변화

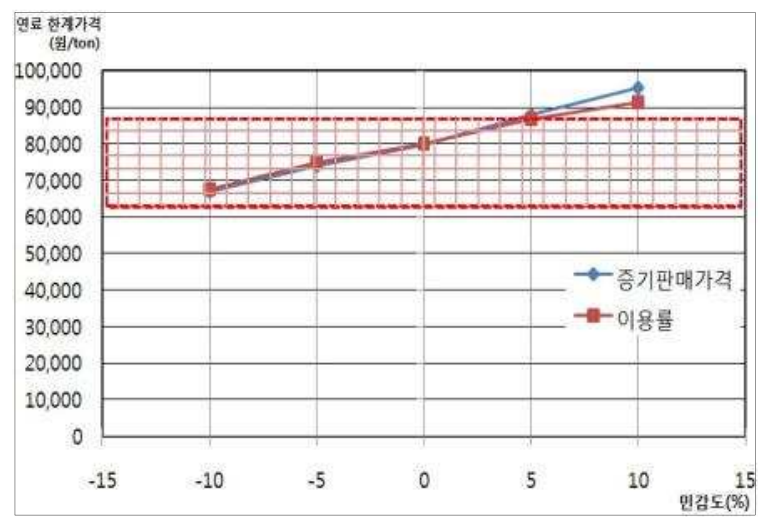

\begin{tabular}{c|c|c|c|c|c}
\hline \multirow{2}{*}{ 구 분 } & 경사도 & $\begin{array}{c}\text { 생산비용 } \\
\text { (원/톤) }\end{array}$ & $\begin{array}{c}\text { 작업로 } \\
\text { (원/m) }\end{array}$ & $\begin{array}{c}\text { 임목대금 } \\
\text { (원/톤) }\end{array}$ & $\begin{array}{c}\text { 공급단가 } \\
\text { (원/톤) }\end{array}$ \\
\hline \hline \multirow{3}{*}{ System1 1} & 완 & 53,197 & 1,024 & & 67,383 \\
\cline { 2 - 4 } & 중 & 55,854 & 1,186 & & 70,202 \\
\cline { 2 - 4 } & 급 & 60,115 & 2,582 & & 75,859 \\
\hline \multirow{3}{*}{ System2 } & 완 & 63,486 & 1,024 & \multirow{4}{*}{13,162} & 77,672 \\
\cline { 2 - 4 } & 중 & 66,142 & 1,186 & 80,490 \\
\cline { 2 - 3 } & 급 & 70,404 & 2,582 & & 86,148 \\
\hline \multirow{3}{*}{ System3 3} & 완 & 49,378 & 1,024 & & 63,563 \\
\cline { 2 - 3 } & 중 & 52,034 & 1,186 & & 66,382 \\
\cline { 2 - 3 } & 급 & 56,296 & 2,582 & & 72,040 \\
\hline
\end{tabular}

Fig. 13. 연료 한계가격과 공급가격 비교

에너지공학 제23권 제1호 2014 


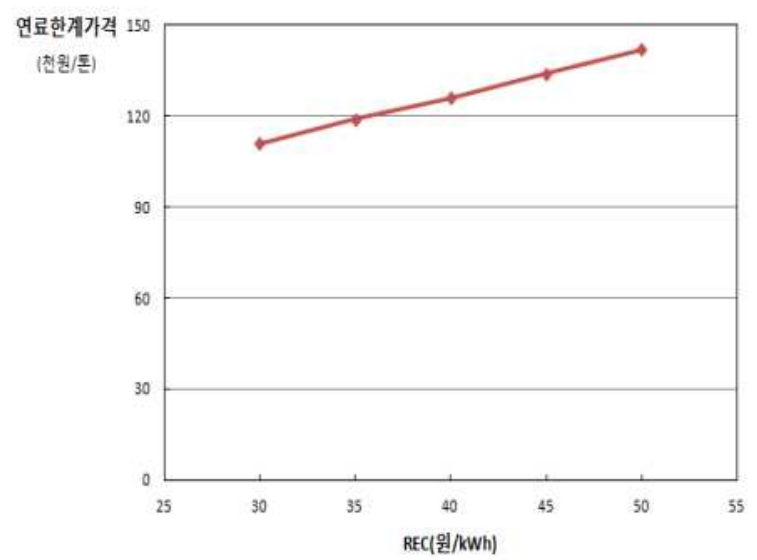

Fig. 14. REC 가격변화에 따른 연료 한계가격 변화

Fig. 13에서 보는 바와 같이 전기 판매단가가 현재 의 SMP보다 낮거나 이용률이 $80 \%$ 이하일 경우에는 system1 system3까지 모든 시스템에서 생산되는 연 료 공급가격이 한계가격을 초과하게 되어 산림 바이 오매스만을 연료로 활용할 때는 경제성이 부족한 것 으로 분석되었으나, 전기 판매단가가 현재의 SMP보 다 높아지거나 이용률을 $80 \%$ 이상으로 향상시킬 경우 산림 바이오매스의 이용이 가능한 것으로 나타났다 $[27,29,30]$.

더구나, 2012년부터 RPS제도가 시행될 경우 목질 계 바이오매스 에너지에 대해 가중치 1.5 를 받게 되 어 REC가격 변화에 따른 한계가격을 산정한 결과 모 든 시스템에서 생산되는 산림 바이오매스의 이용이 충분히 가능한 것으로 판단된다[27,29,30].

\section{5. 결 론}

본 연구에서는 리기다소나무를 에너지 연료로 활 용하기 위해 실증실험을 통해 최적의 생산시스템을 개발하고 이에 따른 연료 생산원가를 분석하였으며 공급가격과 전기·열 판매가격 및 이용률 등을 고려한 우드칩 연료 한계가격을 산출하여 열전용 시설 및 발 전 전용시설에서의 에너지연료 활용을 위한 경제성을 분석하였다.

1) 연료생산 실증실험 및 생산원가 분석

우드칩연료 생산의 경제성분석을 위해 전북 진안 군에 4개 필지(8ha 규모)의 실증단지를 조성하고 작 업로 개설, 벌목, 집재, 파쇄, 운송 등의 작업공정별
산출량, 노동력 및 투입장비, 소모품 등의 투입시간 및 투입량 등을 파악하였으며, 이를 기초로 생산원가 를 산출하였다. 또한 현 기술수준 하에서 최적의 연 료생산시스템으로 5 개의 시스템을 제안하고 각 시스 템별 생산원가를 산출하였다.

5 개의 연료생산시스템은 크게 전목 생산시스템과 전간재 생산시스템으로 구분되며 임지의 작업여건 및 차량의 접근성 등을 고려할 때 벌목(전목)-집재(전 목)-파쇄-운송하는 System1의 생산원가가 가장 낮은 것으로 분석되었다. 또한 임지의 작업여건 및 차량의 접근성 등을 고려하여 전목 생산시스템 또는 전간재 생산시스템을 선택적으로 적용하는 것이 필요하다.

2) 기존의 생산시스템과 전목 생산시스템 비교 시 경제성 높음

4개 필지의 실증단지에서 실험결과 얻은 전목 생 산시스템의 생산원가와 기존 단목 생산시스템의 생산 원가를 비교 했을 때 $40 \sim 56 \%$ 의 절감효과가 나타 나는 것으로 분석되었다.

향후 본 연구에서 투입된 장비가 개량되거나 성능 이 더 좋은 장비가 투입될 될 경우, 또한 보다 숙련된 임업 기술 인력이 투입될 경우 산림 바이오매스 우드 칩 생산원가는 더 낮아질 수 있을 것으로 판단된다.

3) 리기다소나무의 에너지연료 활용을 위한 경제성분석 리기다소나무의 에너지연료 활용에 대한 경제성 분석을 위해 현재 국내에서 열을 공급하고 있는 $\mathrm{A}$ 사 의 투자내역을 참조하여 전기.증기판매 가격과 이용 률의 민감도에 따른 연료 한계가격을 분석하였다. 증기가격과 이용률을 긍정적으로 반영할 경우에는 system1, system2 및 system3의 전목 생산시스템에 서 생산되는 연료는 모두 활용 가능하지만, 증기가격 과 이용률이 부정적인 경우 급경사에서 생산되는 산 림 바이오매스의 사용에는 일부 한계가 있는 것으로 나타났다.

또한 국내에서 발전전기를 전력거래소에 판매하는 $\mathrm{B}$ 사의 자료를 참조하여 전기 판매가격과 이용률의 민감도에 따른 연료 한계가격을 산정하였다. 그 결과 전기 판매단가가 현재의 $\mathrm{SMP}$ 보다 낮거나 이용률이 $80 \%$ 이하일 경우에는 system 1 system3까지 모든 시 스템의 공급가격이 한계가격을 초과하게 되어 산림 바이오매스만을 연료로 활용할 때는 경제성이 부족한 것으로 분석되었으나, 전기 판매단가가 현재의 SMP 보다 높아지거나 이용률을 $80 \%$ 이상으로 향상시킬 경 우에는 산림 바이오매스의 이용이 가능한 것으로 나 
타났다. 더구나, 2012년부터 RPS 제도가 시행 될 경 우 목질계 바이오매스 에너지에 대한 신재생에너지 인증서(REC)편익을 고려할 때 충분히 경쟁력을 갖게 되며 발전원가 측면에서 다른 신재생에너지원보다 우 수한 것으로 판단된다.

따라서, 국내 발전부문에서 RPS 공급 의무율 이 행을 위해서 산림 바이오매스의 활용이 적극 권장된 다.

$$
\text { 감 사 }
$$

본 연구는 2012년 서울과학기술대 교내연구비지원 으로 이루어졌습니다.

\section{참고문헌}

(1)지식경제부, “제2차 국가 에너지 기본계획”, 2010

(2)안지운, "바이오에너지산업 육성을 통한 FTA대 응전략 연구”, 에너지경제연구원, 기본연구보고 서 09-15

(3)강창용. 민경택, “영국 바이오매스 주요정책의 내용과 시사점", 농촌경제 제2권 3호,2006

(4)김재원,박문섭,송태영, “집재작업 강도평가에 관 한 연구”, 산림과학논문집54,1996

(5)김외정, "국산목재자원의 효율적 수요공급방안", 웰빙시대의 국산목재 이용 활성화를 위한 심포 지움 자료집, 임업단체총연합회,2005

(6)김재원, “임목수확작업의 유형별 작업강도 및 작업능률 평가에 관한 연구”, 서울대학교 박사학 위논문,2003

(7)김재원, 노재후, 우태명, 이해주, "간벌 작업의 작업강도 및 집재기계화에 관한 연구”, 임업연구 원연구보고39,1989,

(8)박현태 외 5인, “주요국의 바이오에너지 개발 및 보급동향, 한국농촌경제연구원,2008.3

(9)배정환, 김진오, 조상민, “지역균형발전을 위한 지역에너지사업 추진전략 및 경제적 파급효과 분석", 에너지경제연구원 기본연구보고서 06-18,2006

(10)산림과학원, “경제림육성을 위한 산림실태조 사",2002

(11)산림조합 중앙회, “환경친화적 임목수확모델
개발 및 공정조사 사업”,2002

(12)산업자원부, “목질계 바이오매스의 에너지활용 방안”,2007.2

(13)산업자원부, “제 2 차 신·재생에너지 기술개발 및 이용 보급 기본계획",2003

(14)산업자원부, “신·재생 에너지 발전차액 지원제 도 개선 및 RPS제도와 연계 방안”,2006

(15)산업자원부/에너지관리공단, "04년 대체에너지 보급 통계",2005,

(16)석현덕 외 3 인, "목질바이오매스 열에너지 개 발의 경제성 분석과 에너지용 산림폐재의 지속적 확보방안“, 농촌경제연구원,2005.10

(17)에너지경제연구원/산업자원부, “제 3 차 전력수 급 기본계획(2006 20년)”,2006

(18)에너지경제연구원/산업자원부, “집단 에너지 공급 기본계획 수립에 관한 연구“,2007

(19)유승직, “국제온실가스 감축에 따른 사회적 영 향분석", 에너지경제연구 2000

(20)이준우, "한국 임도의 등급조정에 관한 고 찰, 2007 산림공학기술 심포지움, 한국산림공학기술연구회,2007.

(21)임업연구원, “우리나라산 주요 목재의 성질과 용도”,1994

(22)임업연구원, “임업기계화 장기 기본계획”,1994

(23)임업연구원, “산림사업의 공적관리 시스템강화 및 임산 바이오매스를

이용한 대체 에너지보급“'2003

(24)차두송 외, “국산재 생산비용 절감을 위한 임 도 및 임업기계 활용방안”,2007 산림공학기 술 심포지움, 한국산림공학기술연구회,2007

(25)최돈하, “바이오매스활용 워크샵 발표자료", 산림과학원,2006

(26)최준원, “유럽국가의 목질계 바이오 에너지 활 용현황"산림조합중앙회,2006.8

(27)한국목재칩연합회, "연도별 펄프용 우드칩의 회원사 납품실적”,2006

(28)한국임정연구회, “솦가꾸기산물의 경제적 활용 방안에 관한 연구”,2003

(29)한국지역난방공사, “바이오매스를 활용한 지역 난방시스템 도입타당성 연구”, 한국에너지 기술연구원,2004

(30)산업자원부, “리기다소나무 활용을 위한 경제 성분석”(2008) 